\title{
Contents, Enrichment, Toxicity and Baselines of trace elements in the estuarine and coastal sediments of the Daliao River System, China
}

\author{
Chunye Lin, * Mengchang He, Shaoqing LiU and YAnXia Li \\ State Key Joint Laboratory of Environmental Simulation and Pollution Control, School of Environment, \\ Beijing Normal University, Beijing 100875, China
}

(Received January 12, 2012; Accepted May 12, 2012)

\begin{abstract}
The Daliao River System (DRS) estuary in the Liaodong Bay has a highly industrial, urbanized, and agricultural catchment. The objective of this study was to investigate the multi-elemental geochemistry in the estuarine and coastal sediments, including enrichment, sources, toxicity, and geochemical baselines. Thirty-five sediment samples were collected from the estuarine and coastal area and analyzed for $\mathrm{As}, \mathrm{Cd}, \mathrm{Co}, \mathrm{Cr}, \mathrm{Cu}, \mathrm{Hg}, \mathrm{Ni}, \mathrm{Pb}, \mathrm{Sb}, \mathrm{Sc}, \mathrm{V}, \mathrm{Y}, \mathrm{Zn}, \mathrm{P}, \mathrm{Mn}, \mathrm{Ti}, \mathrm{Al}$, $\mathrm{Fe}, \mathrm{Ca}, \mathrm{Mg}, \mathrm{Na}$, and $\mathrm{K}$. The average content (mg/kg) was 11.4 for $\mathrm{As}, 0.34$ for $\mathrm{Cd}, 10.2$ for Co, 60.8 for $\mathrm{Cr}, 20.0$ for $\mathrm{Cu}$, 0.05 for $\mathrm{Hg}$, 22.6 for $\mathrm{Ni}, 26.6$ for $\mathrm{Pb}, 71.8$ for $\mathrm{Zn}$, and 0.68 for $\mathrm{Sb}$. The enrichment factor (EF) values of the trace elements, relative to the upper continental crust (UCC), ranged from 7.06 for As to 1.04 for Co, using Fe as a reference element. In general, As, Cd, and $\mathrm{Sb}$ were significantly or moderately enriched, while the other trace elements were not or were minimally enriched. The As and $\mathrm{Ni}$ in the sediments may pose potential toxicity to biota, while the $\mathrm{Cd}, \mathrm{Cr}, \mathrm{Cu}, \mathrm{Hg}, \mathrm{Pb}$, and $\mathrm{Zn}$ might rarely or not pose toxicity. All elements except $\mathrm{Ca}, \mathrm{K}$, and $\mathrm{Na}$ were significantly and positively correlated with one another, with correlation coefficients of 0.523 to 0.994 . Principal component analysis (PCA) revealed three groups of elements in association with secondary clay minerals, primary minerals, and carbonate minerals. Generally, the $\mathrm{Cr}$, $\mathrm{Cu}$, $\mathrm{Hg}, \mathrm{Ni}, \mathrm{Pb}$, and $\mathrm{Zn}$ in the sediments originated from natural sources and their regional geochemical baselines (RGBs) were developed using Fe as a reference element. These RGBs may help identify the origins of these metals in the sediments of the Liaodong Bay and document their change over time.
\end{abstract}

Keywords: estuary sediment, trace element, enrichment, toxicity, regional geochemical baseline

\section{INTRODUCTION}

Aquatic sediments react as traps for trace elements, especially for pollutant elements. Thus, the contamination of estuarine sediments by trace elements is a worldwide problem (Bloxam et al., 1972; Thompson et al., 1980; Akagi and Haraguchi, 1994; Krupadam et al., 2006). Consequently, geochemical sediment surveys are important to illustrate the distribution, source, and enrichment of elements or contaminants in estuaries.

The estuary of the Daliao River System (DRS) has a highly urbanized and industrialized catchment. The DRS is the most important watercourse in the Liaoning Province of China. These rivers drain large industrial, urban and agricultural areas. The average annual outputs of $\mathrm{Cu}$, $\mathrm{Pb}$ and $\mathrm{Zn}$ in the province were $70.3 \times 10^{3}, 40.3 \times 10^{3}$ and $265.9 \times 10^{3} \mathrm{t}$, respectively, from 1990 to 2006 (Statistical Bureau of Liaoning Province (SBLP), 2008). In addition, the output of pig iron reached $37.6 \times 10^{6} \mathrm{t}$ in 2006 (SBLP, 2008). The large industrial cities include

\footnotetext{
*Corresponding author (e-mail: c.lin@bnu.edu.cn)
}

Copyright (c) 2012 by The Geochemical Society of Japan.
Fushun, Shenyang, Benxi, Anshan, Liaoyang, Panjin, and Yingkou, with populations of 2.24, 6.98, 1.56, 3.47, 1.82, 1.25 , and 2.30 million, respectively, in 2005 (SBLP, 2008). During the past few decades, large amounts of various synthetic and geogenic pollutants have been discharged into the DRS with a stream of wastewater from industries and municipalities and runoff from agriculture. However, studies on the geochemistry of trace and minor elements in the estuarine sediments of the DRS have not been conducted so far. We previously reported the contents and chemical forms of $\mathrm{Cd}, \mathrm{Cr}, \mathrm{Ni}, \mathrm{Mn}$, and $\mathrm{P}$ in the estuarine sediments of the DRS (Wang et al., 2009; Wu et al., 2011a).

The present study aims to determine the levels of trace, minor, and major elements in the estuarine and coastal sediments of the DRS; to identify the enrichment and sources of trace elements; to estimate the ecological risk; and to assess the regional geochemical baselines of heavy metals in the estuarine and coastal sediments of the DRS.

\section{MATERIALS AND METHODS}

In August 2007 (flood season), surface sediment samples were collected at 35 sites in the Daliao River's estu- 




Fig. 1. Schematic graph of the Daliao River System (Daliao River, Hun River, Taizi River) and its estuary and the sampling sites in the estuarine area. 
Table 1. Analytical results of certified and obtained values of geochemical standard substances (GSS1 and GSS2) from the Institute of Geophysical and Geochemical Exploration (IGGE), Chinese Academy of Geological Sciences

\begin{tabular}{|c|c|c|c|c|c|c|c|c|c|c|c|}
\hline & \multirow[t]{2}{*}{ Unit } & \multicolumn{2}{|c|}{ Certified value } & \multicolumn{4}{|c|}{ Measured value } & \multicolumn{4}{|c|}{ Measured value } \\
\hline & & GSS1 & GSS2 & GSS1 & GSS1 & Mean & Error $\%$ & GSS2 & GSS2 & Mean & Error \% \\
\hline As & $\mathrm{mg} / \mathrm{kg}$ & 34.00 & 13.70 & 33.95 & 33.63 & 33.79 & -0.62 & 13.62 & 13.44 & 13.53 & -1.24 \\
\hline $\mathrm{Cd}$ & $\mathrm{mg} / \mathrm{kg}$ & 4.300 & 0.071 & 4.210 & 4.212 & 4.211 & -2.07 & 0.069 & 0.069 & 0.07 & -3.28 \\
\hline Co & $\mathrm{mg} / \mathrm{kg}$ & 14.20 & 8.70 & 13.13 & 13.25 & 13.19 & -7.11 & 8.25 & 7.99 & 8.12 & -6.67 \\
\hline $\mathrm{Cr}$ & $\mathrm{mg} / \mathrm{kg}$ & 62.00 & 47.00 & 62.80 & 69.40 & 66.10 & 6.61 & 43.10 & 46.87 & 44.99 & -4.29 \\
\hline $\mathrm{Cu}$ & $\mathrm{mg} / \mathrm{kg}$ & 21.00 & 16.30 & 20.12 & 19.69 & 19.91 & -5.20 & 15.40 & 15.17 & 15.29 & -6.22 \\
\hline $\mathrm{Hg}$ & $\mathrm{mg} / \mathrm{kg}$ & 0.032 & 0.015 & 0.031 & 0.031 & 0.031 & -3.37 & 0.016 & 0.014 & 0.01 & -0.96 \\
\hline $\mathrm{Mn}$ & $\mathrm{mg} / \mathrm{kg}$ & 1760.00 & 510.00 & 1769.80 & 1868.00 & 1818.90 & 3.35 & 509.30 & 514.90 & 512.10 & 0.41 \\
\hline $\mathrm{Ni}$ & $\mathrm{mg} / \mathrm{kg}$ & 20.40 & 19.40 & 18.77 & 19.11 & 18.94 & -7.16 & 19.13 & 18.26 & 18.70 & -3.63 \\
\hline $\mathrm{P}$ & $\mathrm{mg} / \mathrm{kg}$ & 735.00 & 446.00 & 790.69 & 782.20 & 786.44 & 7.00 & 451.08 & 432.70 & 441.89 & -0.92 \\
\hline $\mathrm{Pb}$ & $\mathrm{mg} / \mathrm{kg}$ & 98.00 & 20.00 & 100.81 & 98.78 & 99.79 & 1.83 & 20.72 & 20.20 & 20.46 & 2.30 \\
\hline $\mathrm{Sb}$ & $\mathrm{mg} / \mathrm{kg}$ & 0.87 & 1.30 & 0.96 & 0.82 & 0.89 & 1.85 & 1.28 & 1.23 & 1.26 & -3.18 \\
\hline $\mathrm{Sc}$ & $\mathrm{mg} / \mathrm{kg}$ & 11.20 & 10.70 & 10.38 & 10.23 & 10.31 & -7.98 & 10.73 & 10.33 & 10.53 & -1.61 \\
\hline $\mathrm{Ti}$ & $\mathrm{mg} / \mathrm{kg}$ & 4830.00 & 2710.00 & 4690.21 & 4726.00 & 4708.10 & -2.52 & 2751.83 & 2597.00 & 2674.41 & -1.31 \\
\hline V & $\mathrm{mg} / \mathrm{kg}$ & 86.00 & 62.00 & 79.00 & 86.71 & 82.85 & -3.66 & 61.64 & 61.65 & 61.65 & -0.57 \\
\hline $\mathrm{Zn}$ & $\mathrm{mg} / \mathrm{kg}$ & 680.00 & 42.00 & 673.07 & 641.10 & 657.09 & -3.37 & 39.05 & 46.52 & 42.79 & 1.87 \\
\hline $\mathrm{Al}_{2} \mathrm{O}_{3}$ & $\%$ & 14.18 & 10.31 & 14.06 & 14.35 & 14.21 & 0.18 & 10.71 & 10.49 & 10.60 & 2.83 \\
\hline $\mathrm{Fe}_{2} \mathrm{O}_{3}$ & $\%$ & 5.19 & 3.52 & 5.52 & 5.27 & 5.39 & 3.93 & 3.46 & 3.44 & 3.45 & -1.95 \\
\hline $\mathrm{MgO}$ & $\%$ & 1.81 & 1.04 & 1.80 & 1.83 & 1.82 & 0.33 & 1.25 & 1.02 & 1.14 & 9.13 \\
\hline $\mathrm{CaO}$ & $\%$ & 1.72 & 2.36 & 1.76 & 1.77 & 1.77 & 2.78 & 2.37 & 2.36 & 2.36 & 0.18 \\
\hline $\mathrm{Na}_{2} \mathrm{O}$ & $\%$ & 1.66 & 1.62 & 1.69 & 1.64 & 1.66 & 0.05 & 1.93 & 1.54 & 1.74 & 7.12 \\
\hline $\mathrm{K}_{2} \mathrm{O}$ & $\%$ & 2.59 & 2.54 & 2.64 & 2.51 & 2.57 & -0.65 & 2.61 & 2.41 & 2.51 & -1.22 \\
\hline
\end{tabular}

ary and coastal area, the Liaodong Bay, using Van Veen grab (Eijkelkamp, Netherlands) cable-operated sediment samplers (Fig. 1). The samples were placed in plastic bags and brought back to the laboratory, where they were freeze-dried, slightly crushed, passed through a $2 \mathrm{~mm}$ sieve, and stored in glass bottles. The salinity and dissolved oxygen of the water of the studied area, measured in the field using a portable spectrophotometer (DR2400, Hach), ranged from 0.28 to $2.83 \%$ and 1.2 to $7.5 \mathrm{mg} \mathrm{L}^{-1}$, respectively. The $\mathrm{pH}$ value of sediment samples, analyzed in the suspension of 1:10 solid:liquid ratio, ranged 6.0 to 8.0, with an average of 7.6. The dissolved $\mathrm{Fe}$ and $\mathrm{Mn}$ concentration in the porewater of sediment profiles, measured in-situ by the diffusive gradients in thin films (DGT), showed the weak reduction zone (0 to $3 \mathrm{~cm}$ depth), strong reduction zone ( 3 to $4 \mathrm{~cm}$ depth) and moderate reduction zone (4 to $13 \mathrm{~cm}$ depth) (Wu et al., 2011b).

Portions of the sediment samples were digested with $\mathrm{HNO}_{3}-\mathrm{HF}-\mathrm{HClO}_{4}$ (Lin et al., 2008). The $\mathrm{Al}, \mathrm{Fe}, \mathrm{Mg}, \mathrm{Ca}$, $\mathrm{Na}, \mathrm{K}, \mathrm{Ti}, \mathrm{Mn}, \mathrm{P}, \mathrm{Cr}$, and $\mathrm{V}$ in the extracts were measured with ICP-AES (IRIS Intrepid II, Thermo Electron), while the $\mathrm{Cd}, \mathrm{Co}, \mathrm{Cu}, \mathrm{Ni}, \mathrm{Pb}, \mathrm{Sb}, \mathrm{Sc}$, and $\mathrm{Y}$ were measured with ICP MS (X Series II, Thermo Electron). Portions of the soil samples were digested with aqua regia, a $1 \%$ $\mathrm{KMnO}_{4}$ solution, and $1 \%$ oxalic acid. The As and $\mathrm{Hg}$ in the supernatant were determined by hydride generation atomic fluorescence spectrometry (HGAFS) and cold vapor atomic fluorescence spectrometry (CVAFS), respectively. The accuracy of the method was assessed by replicate analyses of the elements in the certified reference materials GSS1 and GSS2 (Institute of Geophysical and Geochemical Exploration (IGGE), Chinese Academy of Geological Sciences). The results are shown in Table 1 and demonstrate that the analytical error (accuracy) ranged from $-7.98 \%$ for Sc to $9.13 \%$ for $\mathrm{Mg}$.

Natural variations in the abundance of mineral matter generally have an important effect on elements in soils and sediments (Loring, 1991; Sutherland, 2000). Therefore, enrichment factors relative to the upper continental crust (UCC) were calculated to evaluate the effect of human activities and weathering. $\mathrm{Al}$ or $\mathrm{Fe}$ is often used as a normalizing element to calculate the enrichment factor of trace elements (TEs) (Mil-Homens et al., 2007). In this study, the enrichment factor (EF) was calculated for all trace elements as

$$
\mathrm{EF}=([\mathrm{TE}] /[\mathrm{Al} \text { or } \mathrm{Fe}])_{\text {Sample }} /([\mathrm{TE}] /[\mathrm{Al} \text { or } \mathrm{Fe}])_{\mathrm{UCC}}
$$

where the concentrations of TE, $\mathrm{Al}$, and $\mathrm{Fe}$ in the UCC were taken from Wedepohl (1995) (Table 2). EF < 2, EF $=2$ to $5, \mathrm{EF}=5$ to $20, \mathrm{EF}=20$ to 40 , and $\mathrm{EF}>40$ suggest no or minimal, moderate, significant, strong, and extreme enrichment or pollution, respectively (Sutherland, 2000). 
Table 2. Average contents of elements in the estuarine and coastal sediments of the Diaoliao River System (DRS), the upper continental crust (UCC), and worldwide sediment (WS)

\begin{tabular}{|c|c|c|c|c|c|c|c|c|c|}
\hline \multirow[t]{2}{*}{ Element } & \multirow[t]{2}{*}{ Unit } & \multicolumn{6}{|c|}{ DRS* } & \multicolumn{2}{|c|}{ Globe** } \\
\hline & & Mean & Std & $\mathrm{CV} \%$ & $\operatorname{Max}$ & Min & Median & UCC & WS \\
\hline As & $\mathrm{mg} / \mathrm{kg}$ & 11.41 & 4.66 & 40.9 & 19.13 & 4.61 & 10.68 & 2.00 & 7.70 \\
\hline $\mathrm{Cd}$ & $\mathrm{mg} / \mathrm{kg}$ & 0.34 & 0.20 & 57.4 & 0.67 & 0.05 & 0.39 & 0.10 & 0.17 \\
\hline Co & $\mathrm{mg} / \mathrm{kg}$ & 10.17 & 4.15 & 40.9 & 16.02 & 3.61 & 10.60 & 11.60 & 14.00 \\
\hline $\mathrm{Cr}$ & $\mathrm{mg} / \mathrm{kg}$ & 60.83 & 16.87 & 27.7 & 85.80 & 15.40 & 65.20 & 35.00 & 72.00 \\
\hline $\mathrm{Cu}$ & $\mathrm{mg} / \mathrm{kg}$ & 20.04 & 11.57 & 57.7 & 43.80 & 2.77 & 21.06 & 14.30 & 33.00 \\
\hline $\mathrm{Hg}$ & $\mathrm{mg} / \mathrm{kg}$ & 0.05 & 0.03 & 63.8 & 0.10 & 0.01 & 0.06 & 0.06 & 0.19 \\
\hline $\mathrm{Ni}$ & $\mathrm{mg} / \mathrm{kg}$ & 22.60 & 10.80 & 47.8 & 38.62 & 5.47 & 23.47 & 18.60 & 52.00 \\
\hline $\mathrm{Pb}$ & $\mathrm{mg} / \mathrm{kg}$ & 26.62 & 7.44 & 27.9 & 39.18 & 16.57 & 26.19 & 17.00 & 19.00 \\
\hline $\mathrm{Zn}$ & $\mathrm{mg} / \mathrm{kg}$ & 71.80 & 36.50 & 50.8 & 125.93 & 16.53 & 76.62 & 52.00 & 95.00 \\
\hline $\mathrm{Sb}$ & $\mathrm{mg} / \mathrm{kg}$ & 0.68 & 0.25 & 37.0 & 1.12 & 0.27 & 0.70 & 0.31 & 1.20 \\
\hline $\mathrm{Sc}$ & $\mathrm{mg} / \mathrm{kg}$ & 8.70 & 3.63 & 41.7 & 14.38 & 2.60 & 9.16 & 7.00 & 10.00 \\
\hline V & $\mathrm{mg} / \mathrm{kg}$ & 58.64 & 17.74 & 30.3 & 81.92 & 14.79 & 62.37 & 53.00 & 105.00 \\
\hline Y & $\mathrm{mg} / \mathrm{kg}$ & 22.74 & 5.11 & 22.5 & 30.13 & 10.17 & 23.77 & 20.70 & 40.00 \\
\hline $\mathrm{P}$ & $\mathrm{mg} / \mathrm{kg}$ & 548.5 & 132.4 & 24.1 & 840.9 & 229.7 & 561.3 & 665.0 & 670.0 \\
\hline $\mathrm{Mn}$ & $\mathrm{mg} / \mathrm{kg}$ & 623.9 & 238.6 & 38.2 & 1073.0 & 264.7 & 622.8 & 527.0 & 770.0 \\
\hline $\mathrm{Ti}$ & $\mathrm{mg} / \mathrm{kg}$ & 3186 & 821 & 25.8 & 4052 & 765 & 3470 & 3117 & 3800 \\
\hline $\mathrm{Al}$ & $\%$ & 6.72 & 1.09 & 16.2 & 7.97 & 3.77 & 7.29 & 7.74 & 7.20 \\
\hline $\mathrm{Fe}$ & $\%$ & 2.61 & 1.02 & 39.2 & 4.19 & 0.67 & 2.91 & 3.09 & 4.10 \\
\hline $\mathrm{Ca}$ & $\%$ & 1.20 & 0.27 & 22.2 & 2.02 & 0.75 & 1.11 & 2.95 & 6.60 \\
\hline $\mathrm{Mg}$ & $\%$ & 1.24 & 0.37 & 29.9 & 1.67 & 0.34 & 1.40 & 1.35 & 1.40 \\
\hline $\mathrm{Na}$ & $\%$ & 2.39 & 0.41 & 17.2 & 3.22 & 1.63 & 2.28 & 2.57 & 0.57 \\
\hline K & $\%$ & 2.46 & 0.12 & 4.9 & 2.87 & 2.29 & 2.43 & 2.87 & 2.00 \\
\hline
\end{tabular}

*Std, standard deviation; $C V$, coefficient of variance; Max, maximum; Min, minimum.

**Data sources: UCC (Wedepohl, 1995), WS (Bowen, 1979).

\section{RESUlTS AND DisCUSSIONS}

Contents of major, minor, and trace elements in the estuarine and coastal sediments

The averages, standard deviations, and ranges of major, minor, and trace elements in the estuarine and coastal sediments of the DRS are summarized in Table 2.

Major and minor elements As shown in Table 2, Al was the most abundant major element in the sediment $(3.8$ $8.0 \%)$, followed by $\mathrm{Fe}(0.7-4.2 \%)$, Na $(1.6-3.2 \%), \mathrm{K}$ (2.3-2.9\%), $\mathrm{Mg}(0.3-1.8 \%)$, and $\mathrm{Ca}(0.8-2.0 \%)$. The $\mathrm{Ti}$, $\mathrm{Mn}$, and $\mathrm{P}$ contents were within the range of $230-841$, 265-1073, and 765-4052 $\mathrm{mg} \mathrm{kg}^{-1}$, respectively. The lowest fluctuation (spatial variation), indicated by the coefficient of variance $(\mathrm{CV} \%)$, was observed for K $(4.9 \%)$, while the largest was observed for $\mathrm{Fe}(39.5 \%)$ and $\mathrm{Mn}$ $(38.2 \%)$. Fe and $\mathrm{Mn}$ are generally present in the secondary oxides, which may lead to their high spatial variation in content. The composition of major and minor elements in the estuarine and coastal sediments of the DRS is similar to that for the UCC, but quite different from that for sediments throughout the world. Therefore, it is reasonable to judge the enrichment of trace elements in the estuarine and coastal sediments of the DRS relative to the $\mathrm{UCC}$.
Trace elements The average contents of trace elements ranged from $0.05 \mathrm{mg} \mathrm{kg}^{-1}$ for $\mathrm{Hg}$ to $71.8 \mathrm{mg} \mathrm{kg}^{-1}$ for $\mathrm{Zn}$. The contents of some trace elements in the estuarine and coastal sediments (Table 2) were highly variable: $\mathrm{Hg}, \mathrm{Cu}$, $\mathrm{Cd}$, and $\mathrm{Zn}$ accounted for more than $50 \%$ of $\mathrm{CV}$. The lowest fluctuation was observed for Y, with $22.5 \%$ of CV. The contents of $\mathrm{Cd}, \mathrm{As}$, and $\mathrm{Sb}$ in the estuarine and coastal sediments were much higher than those in the UCC, while the contents of other trace elements in the estuarine and coastal sediments was similar to those in the UCC.

Accornero et al. (2008) summarized sediment concentrations of trace metals for world estuaries and coasts. They showed that the contents (in $\mathrm{mg} / \mathrm{kg}$ ) in the estuarine sediments were within the range of 3.3-244 for As, 0.2-42.8 for $\mathrm{Cd}, 38-428$ for $\mathrm{Cr}, 1.8-466$ for $\mathrm{Cu}, 0.4-98$ for $\mathrm{Hg}, 18-56$ for $\mathrm{Ni}, 3-1890$ for $\mathrm{Pb}$, and $0.4-16880$ for $\mathrm{Zn}$. Thus, whereas the contents of these trace metals in the estuarine sediment of DRS were within the range observed for other estuarine sediments, the maximal contents of these trace elements were much lower than the reported upper limits. For example, the $\mathrm{Co}, \mathrm{Sb}$, and $\mathrm{Sc}$ contents in the estuarine sediments of the DRS were similar to those for the Ganges-Brahmaputra estuarine sediment in India (Stummeyer et al., 2002), while the V content was similar to that for Baltic Sea sediments (Szefer 


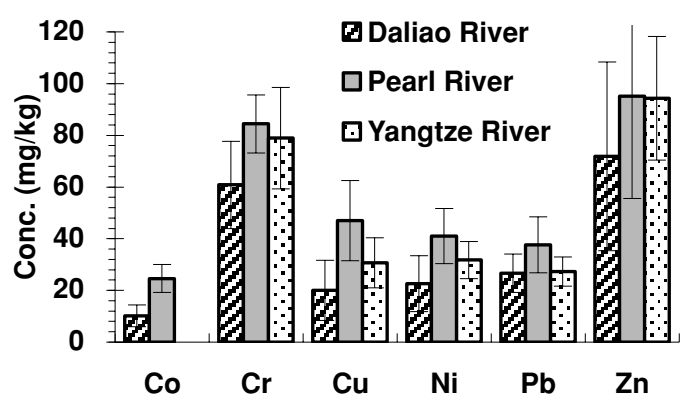

Fig. 2. Comparison of trace element contents in the estuarine and coastal sediments of the DRS with those in the estuarine sediments of the Pearl River $(n=38)$ and the Yangtze River ( $n$ $=59$ ).

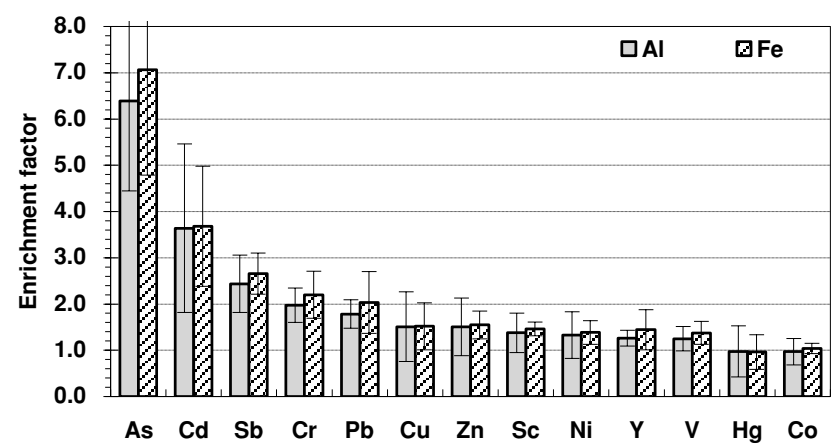

Fig. 3. EF values of trace elements in the estuarine and coastal sediments of the DRS using $A l$ and $F e$ as reference elements. (The error bars represent the spatial variation of EF values in the studied area, $n=35$ ).

et al., 2009). In addition, the contents of $\mathrm{Co}, \mathrm{Cr}, \mathrm{Cu}, \mathrm{Ni}$, $\mathrm{Pb}$, and $\mathrm{Zn}$ were lower in the estuarine sediment of DRS than in the estuarine sediments of the Pearl River (Wang et al., 2008) and the Yangtze River (Zhang et al., 2009) (Fig. 2). The Hg content in the estuarine sediment of DRS was slightly higher than that ( 0.01 to $\left.0.03 \mathrm{mg} \mathrm{kg}^{-1}\right)$ in the sediments of the Huanghe (Yellow River) estuary (Lu et al., 1990), but much lower than that (0.05 to $2.57 \mathrm{mg}$ $\mathrm{kg}^{-1}$ ) in the sediments of coastal British Columbia near Vancouver (Thompson et al., 1980). Therefore, the estuarine sediments of the DRS generally contained lower $\mathrm{Co}, \mathrm{Cr}, \mathrm{Cu}, \mathrm{Ni}, \mathrm{Pb}, \mathrm{Zn}$ and $\mathrm{Hg}$ than the abovementioned sediments in other estuaries or coasts.

To quantify the possible anthropogenic impacts, the EF values relative to the UCC were calculated for each element using equation (1) (Fig. 3). The average EF value ranged from 6.39 for As to 0.97 for Co or from 7.06 for As to 1.04 for $\mathrm{Co}$ using $\mathrm{Al}$ or $\mathrm{Fe}$ as normalizing elements, respectively. The EF values decreased in the following order: $\mathrm{As}, \mathrm{Cd}, \mathrm{Sb}, \mathrm{Cr}, \mathrm{Pb}, \mathrm{Cu}, \mathrm{Zn}, \mathrm{Sc}, \mathrm{Ni}, \mathrm{V}, \mathrm{Y}, \mathrm{Hg}$, and
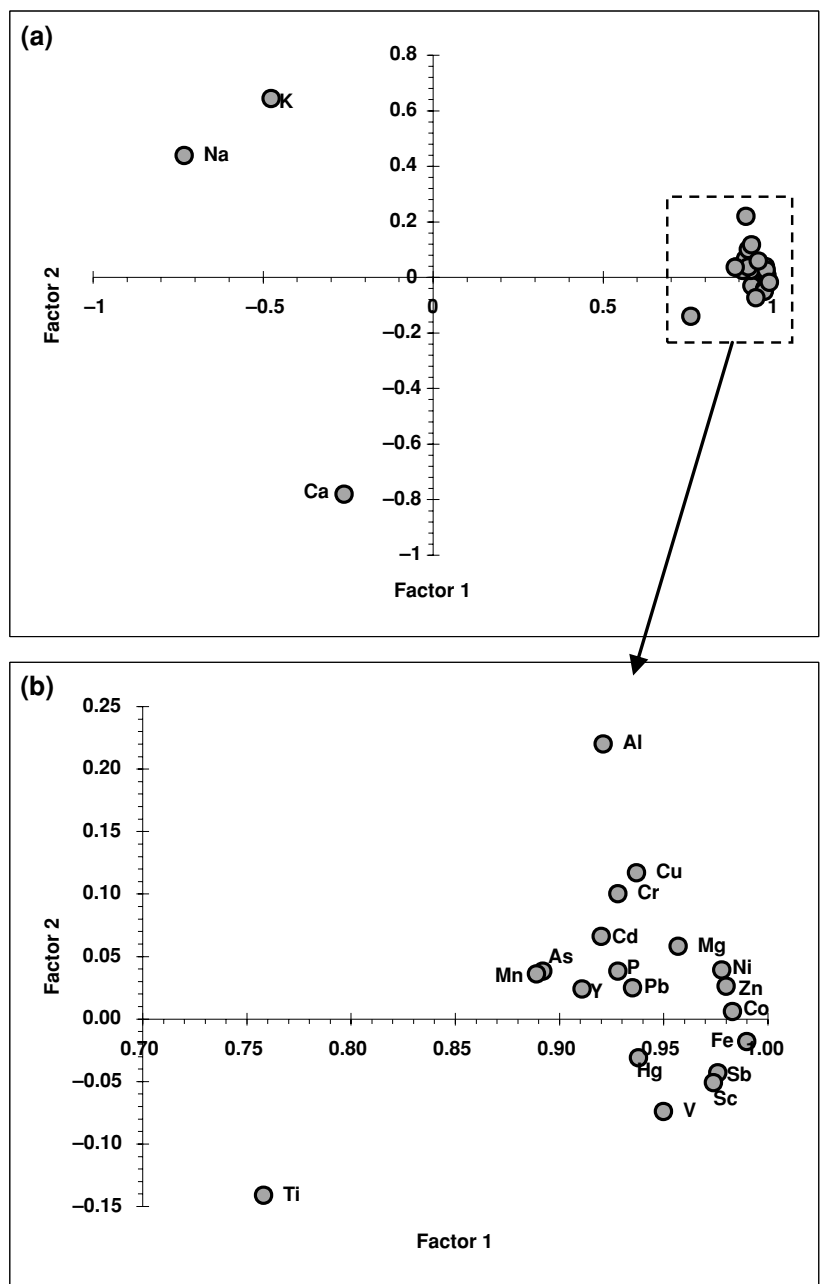

Fig. 4. Principal component score plots of major, minor, and trace elements in the estuarine and coastal sediments of the DRS.

Co. In general, As was significantly enriched, while $\mathrm{Cd}$ and $\mathrm{Sb}$ were moderately enriched. However, $\mathrm{Cr}, \mathrm{Pb}, \mathrm{Cu}$, $\mathrm{Zn}, \mathrm{Sc}, \mathrm{Ni}, \mathrm{Y}, \mathrm{V}, \mathrm{Hg}$, and Co were not or were only minimally enriched.

However, the origin (i.e., natural or anthropogenic) of an element can be distinguished based on the EF value (Liu et al., 2003). Elements having EF values $<1$ are taken to represent a natural origin, whereas values $>1$ might indicate enrichment due to anthropogenic inputs (MilHomens et al., 2006). The mean EF for the elements in the estuarine and coastal sediments in Fig. 4 showed that the poorly enriched elements, $\mathrm{Cr}, \mathrm{Pb}, \mathrm{Cu}, \mathrm{Zn}, \mathrm{Sc}, \mathrm{Ni}, \mathrm{Y}$, $\mathrm{V}, \mathrm{Hg}$, and $\mathrm{Co}$, might be of natural origin, whereas the moderately and significantly enriched elements, As, Cd, and $\mathrm{Sb}$, might partly originate from anthropogenic sources associated with industrial effluents and atmospheric deposition. For example, $1.410 \mathrm{~kg}$ of As and 5150 of $\mathrm{Cd}$ were 


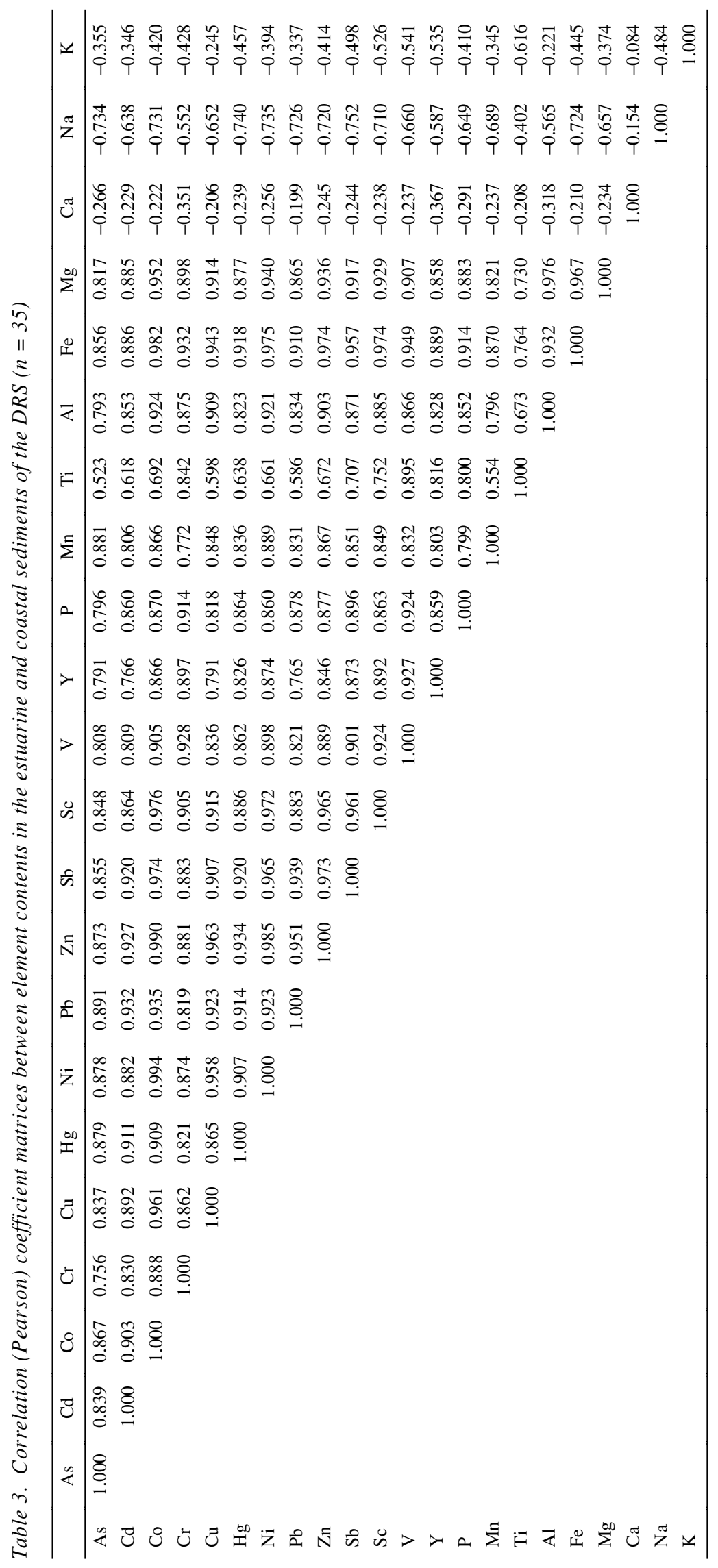



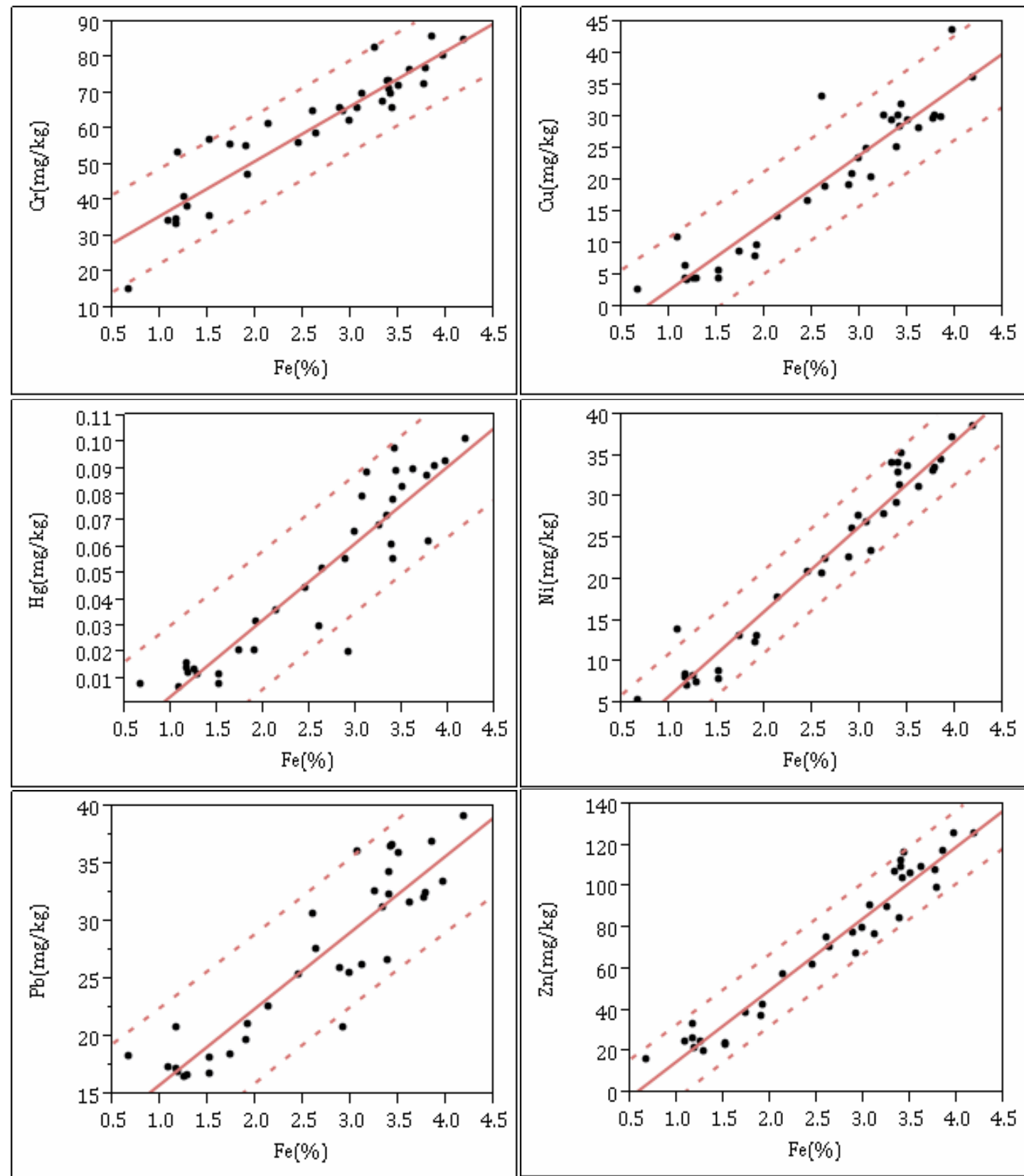

Fig. 5. Contents of $\mathrm{Cr}, \mathrm{Cu}, \mathrm{Hg}, \mathrm{Ni}, \mathrm{Pb}$, and $\mathrm{Zn}$ were plotted against Fe content in the estuarine sediments of the DRS. Linear regression lines and $\pm 95 \%$ prediction limits are superimposed on the data.

discharged into the Liao River System with industrial effluents in 1985 (Su et al., 2010). Emission from coal combustion was about $15400 \mathrm{~kg}$ for Sb in 2009 and $6870 \mathrm{~kg}$ for $\mathrm{Cd}$ in 2008 in the Liaoning province (Tian et al., 2012a, b), while As emission from coal-fired power plants was $40,000 \mathrm{~kg}$ in 2007 (Tian et al., 2011).

\section{Element interrelations and sources}

Correlation (Pearson) and principal component analy- sis (PCA) have often been performed to assess element interrelations and origins ( $\mathrm{Li}$ et al., 2000). The correlation coefficient matrix for the element content in the estuarine and coastal sediments of the DRS is listed in Table 3 .

The correlation between any two trace elements (As, $\mathrm{Cd}, \mathrm{Co}, \mathrm{Cr}, \mathrm{Hg}, \mathrm{Ni}, \mathrm{Pb}, \mathrm{Sb}, \mathrm{Sc}, \mathrm{V}, \mathrm{Y}$, and $\mathrm{Zn}$ ), minor elements $(\mathrm{P}, \mathrm{Mn}$, and $\mathrm{Ti})$ and major elements $(\mathrm{Al}, \mathrm{Fe}$, and $\mathrm{Mg}$ ) was significant at a 0.01 level, with a maximal cor- 
Table 4. Regression parameters for trace metal vs. Fe in the estuarine and coastal sediments of the DRS. All relationships were significant at $p<0.0001$

\begin{tabular}{llcl}
\hline & Formula for RGB & $R^{2}$ & $n$ \\
\hline $\mathrm{Cr}$ & $\mathrm{Cr}(\mathrm{mg} / \mathrm{kg})=15.38 \times \mathrm{Fe}(\%)+19.84$ & 0.932 & 31 \\
$\mathrm{Cu}$ & $\mathrm{Cu}(\mathrm{mg} / \mathrm{kg})=10.27 \times \mathrm{Fe}(\%)-7.49$ & 0.942 & 33 \\
$\mathrm{Hg}$ & $\mathrm{Hg}(\mathrm{mg} / \mathrm{kg})=0.030 \times \mathrm{Fe}(\%)-0.025$ & 0.893 & 34 \\
$\mathrm{Ni}$ & $\mathrm{Ni}(\mathrm{mg} / \mathrm{kg})=10.64 \times \mathrm{Fe}(\%)-5.41$ & 0.965 & 34 \\
$\mathrm{~Pb}$ & $\mathrm{~Pb}(\mathrm{mg} / \mathrm{kg})=6.60 \times \mathrm{Fe}(\%)+9.41$ & 0.875 & 33 \\
$\mathrm{Zn}$ & $\mathrm{Zn}(\mathrm{mg} / \mathrm{kg})=34.75 \times \mathrm{Fe}(\%)-19.00$ & 0.949 & 35 \\
\hline
\end{tabular}

relation coefficient of 0.994 for Co vs. $\mathrm{Ni}$ and a minimal correlation coefficient of 0.523 for As vs. Ti. The correlation coefficients between trace element contents ranged from 0.756 to 0.994 . All trace elements were positively and significantly correlated with $\mathrm{Al}$ and $\mathrm{Fe}$, with average correlation coefficients of 0.868 (0.793 to 0.924$)$ and 0.934 ( 0.856 to 0.934$)$, respectively. In addition, the correlation coefficients of Fe vs. As (0.856) and Cd (0.886) were lower than those for $\mathrm{Fe}$ vs. other trace elements, indicating that $\mathrm{As}$ and $\mathrm{Cd}$ in the estuarine and coastal sediments might be impacted by anthropogenic sources. $\mathrm{Ca}, \mathrm{Na}$, and $\mathrm{K}$ were negatively correlated with other elements. Na was positively and significantly correlated with $\mathrm{K}$. A positive correlation of trace elements with $\mathrm{Fe}$ and a negative correlation of trace elements with $\mathrm{Ca}$ were observed for the estuarine and coastal sediments of the Pearl River (Li et al., 2000; Liu et al., 2003). The high correlation between trace elements and $\mathrm{Fe}, \mathrm{Al}$, and $\mathrm{Mn}$ might be due to their adsorption, co-precipitation, and isomorphous substitution on/in Fe, Al, and Mn minerals (Sparks, 2003).

Principal component analysis (PCA) is used to reduce a large number of variables to a few component variables that explain most of the variability. In the PCA of elemental contents, the first two principal components account for $85.4 \%$ of the total variance, with the first principle component (F1) accounting for $79.3 \%$ of the total variance. The PCA factor loadings of the different elements are plotted in Fig. 4.

The PCA results show there were three groups of elements: the first group (As, $\mathrm{Cd}, \mathrm{Co}, \mathrm{Cr}, \mathrm{Cu}, \mathrm{Hg}, \mathrm{Ni}, \mathrm{Pb}$, $\mathrm{Sb}, \mathrm{Sc}, \mathrm{Zn}, \mathrm{Y}, \mathrm{P}, \mathrm{Mn}, \mathrm{Ti}, \mathrm{Al}, \mathrm{Fe}$, and $\mathrm{Mg}$ ), the second group (Na and $\mathrm{K}$ ), and the third group (Ca) (Fig. 4(a)).

The first group (79.3\% of the total variance) includes most of the elements. The loading values for this element group on F1 ranged from 0.76 for Ti to 0.99 for Fe. This group generally represents secondary clay minerals and the trace elements associated with them. Whereas $\mathrm{Al}$ and Ti were included in the first group, their positions in Fig. 4(b) were relatively far from the other elements in this group. Al generally occurs in both secondary minerals

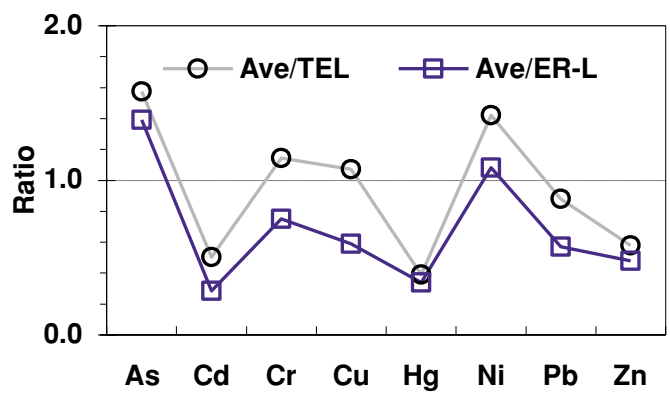

Fig. 6. Ratios of average elemental contents in the estuarine sediment of DRS to the threshold effect level (TEL) and effects range low (ER-L) benchmarks (MacDonald et al., 1996).

(e.g., aluminum oxides and silicate clay) and primary minerals (e.g., feldspars) (Sparks, 2003). Thus, the loading of $\mathrm{Al}$ on the second factor (F2) was relatively high (0.22). However, Ti generally forms minerals in primary igneous and metamorphic rocks, which, because of their resistance to weathering, persist in the derived soils and sediments as resistant heavy minerals (Fitzpatrick and Chittleborough, 2002). Previous studies documented that secondary clay colloid minerals are usually the major factor controlling and binding trace elements in the estuarine and coastal sediments of the Pearl River (Li et al., 2000; Liu et al., 2003).

The secondary group ( $6.1 \%$ of the total variance) includes $\mathrm{Na}$ and $\mathrm{K}$, with relatively high negative loading $(-0.73$ and -0.48$)$ on $F 1$ and relatively high positive loading on F2 (0.44 and 0.64). This group may represent primary minerals, such as feldspars and muscovite, because they are the major primary minerals in the soils of this area.

The third group (5.4\% of the total variance) only includes $\mathrm{Ca}$, with negative loading on both $\mathrm{F} 1$ and $\mathrm{F} 2$. Ca occurs in the secondary carbonate minerals and organism relics (e.g., shell pieces) in the estuarine and coastal environment.

Regional geochemical baselines of selected trace elements

Scatter plots of the metals against the reference element for non-contaminated samples within a geographically coherent area allow the definition of regression lines representing the regional geochemical baseline (RGB). The natural population can be defined by the $95 \%$ confidence interval of the plotted population (Loring and Rantala, 1992). The correlation between Fe or $\mathrm{Al}$ and trace metal concentrations has been used to develop the RGB model in other estuarine sediments around the world (Schropp et al., 1990; Mil-Homens et al., 2007; Newman and Watling, 2007; Lin et al., 2007).

The EF values indicated that $\mathrm{Cr}, \mathrm{Cu}, \mathrm{Hg}, \mathrm{Ni}, \mathrm{Pb}$, and $\mathrm{Zn}$ in the estuarine and coastal sediments of the DRS gen- 
erally originate from natural sources. In addition, their contents are significantly correlated with the contents of the mineral matrix elements, such as Fe and Al. Furthermore, the correlation coefficients of trace metals vs. Fe are higher than those for trace metal vs. Al. Therefore, the dataset can be used to develop the RGB of these six trace metals using $\mathrm{Fe}$ as a reference element.

The plots between trace metals $\mathrm{Cr}, \mathrm{Cu}, \mathrm{Hg}, \mathrm{Ni}, \mathrm{Pb}$, and $\mathrm{Zn}$ and $\mathrm{Fe}$ are presented in Fig. 5. All points that fall inside the $95 \%$ confidence band of metal versus Fe concentrations are characterized as natural sediments, whereas the sampling points that fall above the $95 \%$ confidence limit are considered a metal-enriched population. The data points falling outside the $95 \%$ confidence band were removed, and the remaining data points were used to develop the RGB of the trace metals in the estuarine and coastal sediments of the DRS (Table 4). The correlation coefficients for the formula ranged from 0.875 to 0.965 . All relationships were significant at $p<0.0001$. These RGB models provide the basis for future assessments of the metal contamination in other estuarine and coastal sediments of the DRS.

\section{Potential level of biological risk}

To define the potential level of biological risk associated with the contents of trace metals in the estuarine sediments of DRS, our data were compared with the threshold effect level (TEL) and effects range low (ERL) benchmarks (MacDonald et al., 1996). These indexes can be used to estimate the contents of trace metals that are most likely causing toxicity and to identify sites where adverse biological effects are possible. The TEL is the geometric mean of the 15 th percentile in the effects data set and the 50th percentile in the no effects data set. The ER-L is the 10th percentile in the effects data set. Generally, sediments were considered "nontoxic" when the contents were lower than the ER-L and TEL values, "rarely toxic" when the contents were lower than the ER-L but higher than the TEL, and "potentially toxic" when the contents were higher than both the TEL and ER-L (MacDonald et al., 1996; Accornero et al., 2008). The ratios of the average contents of trace metals to the TEL and ER-L are shown in Fig. 6 for the estuarine sediments of DRS.

The ratios of the As and $\mathrm{Ni}$ contents in the sediment to the TEL and ER-L were $>1.0$, indicating that the As and $\mathrm{Ni}$ in the sediment might pose potential toxicity to biota such as amphipods (MacDonald et al., 1996). The ratios of the $\mathrm{Cr}$ and $\mathrm{Cu}$ contents in the sediment to the TEL were $>1.0$, while their ratios to the ER-L were $<1.0$. Thus, $\mathrm{Cr}$ and $\mathrm{Cu}$ in the sediment would rarely pose toxicity to biota. The ratios of the $\mathrm{Cd}, \mathrm{Hg}, \mathrm{Pb}$, and $\mathrm{Zn}$ contents to the TEL and ER-L were $<1.0$, showing that these four metals would not pose toxicity to biota.

\section{Conclusions}

In general, the composition of the major and minor elements, except $\mathrm{Ca}$, in the estuarine and coastal sediments of the DRS was similar to that of the upper continental crust (UCC). The contents of Fe and Mn, mainly in the secondary minerals, had the largest degree of spatial variance. The contents of $\mathrm{As}, \mathrm{Cd}$, and $\mathrm{Sb}$ in the estuarine and coastal sediments of the DRS were much higher than those in the UCC, while the contents of the other trace elements were similar to those in the UCC.

The EF values decreased in the following order: As, $\mathrm{Cd}, \mathrm{Sb}, \mathrm{Cr}, \mathrm{Pb}, \mathrm{Cu}, \mathrm{Zn}, \mathrm{Sc}, \mathrm{Ni}, \mathrm{V}, \mathrm{Y}, \mathrm{Hg}$, and Co. The poorly enriched elements $(\mathrm{Cr}, \mathrm{Pb}, \mathrm{Cu}, \mathrm{Zn}, \mathrm{Sc}, \mathrm{Ni}, \mathrm{V}, \mathrm{Y}$, $\mathrm{Hg}$, and $\mathrm{Co}$ ) may be of natural origin, while the significantly or moderately enriched elements (As, Cd, and Sb) may have partly originated from anthropogenic sources, such as industrial effluents and atmospheric deposition.

The trace elements, minor elements, and $\mathrm{Al}, \mathrm{Fe}$, and $\mathrm{Mg}$ were positively correlated with one another, while they negatively correlated with $\mathrm{Ca}, \mathrm{Na}$, and $\mathrm{K}$. PCA analysis revealed three groups of elements: the elements in or associated with the secondary clay minerals, the elements in the primary minerals, and the elements in carbonate minerals.

Fe was successfully used as a normalizing tracer to develop RGBs of $\mathrm{Cr}, \mathrm{Cu}, \mathrm{Hg}, \mathrm{Ni}, \mathrm{Pb}$, and $\mathrm{Zn}$ in the estuarine and coastal sediments of the DRS. These RGBs help identify the origins of these metals in the sediments of the Liaodong Bay and document their change over time.

As and $\mathrm{Ni}$ in the sediments may pose toxicity to the biota, while $\mathrm{Cd}, \mathrm{Hg}, \mathrm{Pb}$, and $\mathrm{Zn}$ would not pose toxicity.

Acknowledgments-This study was supported by the National Natural Science Foundation of China (40971058) and the Program for Changjiang Scholars and Innovative Research Team in University (No. IRT0809).

\section{REFERENCES}

Accornero, A., Gnerre, R. and Manfra, L. (2008) Sediment concentrations of trace metals in the Berre Lagoon (France): An assessment of contamination. Arch. Environ. Contam. Toxicol. 54, 372-385.

Akagi, T. and Haraguchi, H. (1994) The surface of particles in Tamagawa estuary and Tokyo Bay and their influence on the distribution of trace elements. Geochem J. 28, 81-97.

Bloxam, T. W., Aurora, S. N., Leach, L. and Rees, T. R. (1972) Heavy metals in some river and bay sediments near Swansea. Nature 239, 158-159.

Bowen, H. J. M. (1979) Environmental Chemistry of the Elements. Academic Press, London.

Fitzpatrick, R. W. and Chittleborough, D. J. (2002) Titanium and zirconium minerals. Soil Mineralogy with Environmental Application (Dixon, J. B. and Schulze, D. G., eds.), 667690, SSSA, Madison. 
Krupadam, R. J., Smita, P. and Wate, S. R. (2006) Geochemical fractionation of heavy metals in sediments of the Tapi estuary. Geochem J. 40, 513-522.

Li, X. D., Wai, O. W. H., Li, Y. S., Coles, B. J., Ramsey, M. H. and Thornton, I. (2000) Heavy metal distribution in sediment profiles of the Pearl River estuary, South China. Appl. Geochem. 15, 567-581.

Lin, C., He, M. C., Zhou, Y. X., Hu, L. J., Guo, W., Quan, X. C. and Yang, Z. F. (2007) Mercury contamination and dynamics in the sediment of the second Songhua River, China. Soil Sediment. Contam. 16, 397-411.

Lin, C., He, M. C., Zhou, Y. X., Guo, W. and Yang, Z. F. (2008) Distribution and contamination assessment of heavy metals in sediment of the Second Songhua River, China. Environ. Monit. Assess. 137, 329-342.

Liu, W. X., Li, X. D., Shen, Z. G., Wang, D. C., Wai, O. W. H. and Li, Y. S. (2003) Multivariate statistical study of heavy metal enrichment in sediments of the Pearl River Estuary. Environ. Pollut. 121, 377-388.

Loring, D. H. (1991) Normalization of heavy-metal data from estuarine and coastal sediments. ICES J. Mar. Sci. 48, 101115.

Loring, D. H. and Rantala, R. T. T. (1992) Manual for the geochemical analyses of marine sediments and suspended particulate matter. Earth Sci. Rev. 32, 235-283.

Lu, X. K., Yang, M., Shi, J. D. and Feng, X. J. (1990) The effect of Huanghe River runoff on the occurrence, transportation and speciation of mercury in the Huanghe Estuary and adjacent sea. Geochem J. 24, 295-308.

MacDonald, D. D., Carr, R. S., Calder, F. D., Long, E. R. and Ingersoll, C. G. (1996) Development and evaluation of sediment quality guidelines for Florida coastal waters. Ecotox. 5, 253-278.

Mil-Homens, M., Stevens, R. L., Abrantes, F. and Cato, I. (2006) Heavy metal assessment for surface sediments from three areas of the Portuguese continental shelf. Continental Shelf Res. 26, 1184-1205.

Mil-Homens, M., Stevens, R. L., Cato, I. and Abrantes, F. (2007) Regional geochemical baselines for Portuguese shelf sediments. Environ. Pollut. 148, 418-427.

Newman, B. K. and Watling, R. J. (2007) Definition of baseline metal concentrations for assessing metal enrichment of sediment from the south-eastern Cape coastline of South Africa. Water SA 33, 675-691.

Schropp, S. J., Lewis, F. G., Windom, H. L., Ryan, J. D., Calder, F. D. and Burney, L. C. (1990) Interpretation of metal concentrations in estuarine sediments of Florida using alumunium as a reference element. Estuaries 13, 227-235.

Sparks, D. L. (2003) Environmental Soil Chemistry. Academic Press, Amsterdam.

Statistical Bureau of Liaoning Province (SBLP) (2008) Statistical Yearbook of Liaoning Province. China Statistics Press,
Beijing.

Stummeyer, J., Marchig, V. and Knabe, W. (2002) The composition of suspended matter from Ganges-Brahmaputra sediment dispersal system during low sediment transport season. Chem. Geol. 185, 125-147.

Su, D., Wang, T., Liu, L. L. and Bai, L. (2010) Research on the spatio-temporal variation of pollutant discharged from industrial wastewater in the Liaohe River Basin. Ecol. Environ. Sci. 19, 2953-2959 (in Chinese).

Sutherland, R. A. (2000). Bed sediment-associated trace metals in an urban stream, Oahu, Hawaii. Environ. Geol. 39, 611-627.

Szefer, P., Glasby, G. P., Geldon, J., Renner, R. M., Bjorn, E., Snell, J., Frech, W. and Warzocha, J. (2009) Heavy-metal pollution of sediments from the Polish exclusive economic Baltic Sea. Environ. Geol. 57, 847-862.

Thompson, J. A. J., MacDonald, R. W. and Wong, C. S. (1980) Mercury geochemistry in sediments of a contaminated fjord of Coastal British Columbia. Geochem J. 14, 71-82.

Tian, H. Z., Wang, Y., Xue, Z. G., Qu, Y. P., Chai, F. H. and Hao, J. M. (2011) Atmospheric emissions estimation of $\mathrm{Hg}$, As, and Se from coal-fired power plants in China, 2007. Sci. Total Environ. 409, 3078-3081.

Tian, H. Z., Cheng, K., Wang, Y., Zhao, D., Lu, L., Jia, W. X. and Hao, J. M. (2012a) Temporal and spatial variation characteristics of atmospheric emissions of $\mathrm{Cd}, \mathrm{Cr}$, and $\mathrm{Pb}$ from coal in China. Atmos. Environ. 50, 157-163.

Tian, H. Z., Zhao, D., Cheng, K., Lu, L., He, M. C. and Hao, J. M. (2012b) Anthropogenic atmospheric emissions of antimony and its spatial distribution characteristics in China. Environ. Sci. Technol. 46, 3973-3980.

Wang, P., He, M. C., Lin, C., Men, B., Liu, R. M., Quan, X. C. and Yang, Z. F. (2009) Phosphorus distribution in the estuarine sediments of the Daliao river, China. Estuar. Coast Shelf S. 84, 246-252.

Wang, S. S., Cao, Z. M., Lan, D. Z., Zheng, Z. C. and Li, G. H. (2008) Concentration distribution and assessment of several heavy metals in sediments of west-four Pearl River Estuary. Environ. Geol. 55, 963-975.

Wedepohl, K. H. (1995) The composition of the continental crust. Geochim. Cosmochim. Acta 59, 1217-1239.

Wu, Z. H., He, M. C., Lin, C. and Fan, Y. H. (2011a) Distribution and speciation of four heavy metals $(\mathrm{Cd}, \mathrm{Cr}, \mathrm{Mn}$ and $\mathrm{Ni}$ ) in the surficial sediments from estuary in Daliao River and Yingkou Bay. Environ. Earth Sci. 63, 63-175.

Wu, Z. H., He, M. C. and Lin, C. (2011b) In situ measurements of concentrations of $\mathrm{Cd}, \mathrm{Co}, \mathrm{Fe}$ and $\mathrm{Mn}$ in estuarine porewater using DGT. Environ. Pollut. 159, 1123-1128.

Zhang, W. G., Feng, H., Chang, J. N., Qu, J. G., Xie, H. X. and $\mathrm{Yu}$, L. Z. (2009) Heavy metal contamination in surface sediments of Yangtze River intertidal zone: An assessment from different indexes. Environ. Pollut. 157, 1533-1543. 